\title{
Extracting Children's Behavioral Characteristics for Acquiring Language from Texts of Picture Book Reviews
}

\author{
Hiroshi Uehara $^{1}$, Mizuho Baba ${ }^{2}$, Takehito Utsuro ${ }^{3}$ \\ ${ }^{1}$ Graduate School of Systems and Information Engineering, \\ University of Tsukuba, \\ 1-1-1 Tennodai, Tsukuba, 305-8573, Japan \\ Corporate Sales and Marketing Division, NTT DOCOMO, INC., \\ Tokyo, 100-6150, Japan \\ E-mail: hiroue@carrot.ocn.ne.jp \\ ${ }^{2}$ Graduate School of Systems and Information Engineering, \\ University of Tsukuba, \\ 1-1-1 Tennodai, Tsukuba, 305-8573, Japan E-mail: mzhbaba@gmail.com \\ ${ }^{3}$ Graduate School of Systems and Information Engineering, \\ University of Tsukuba, \\ 1-1-1 Tennodai, Tsukuba,305-8573, JapanE-mail: utsuro@iit.tsukuba.ac.jp
}

\begin{abstract}
Pointing behavior in childhood is typical developmental sign having strong correlation to his or her language development. This paper focuses on the pointing behavior accompanied by utterance during picture book reading. With this respect, we make use of picture books' review data amounting to approximately 330 thousand, and analyze the reviews reflecting the pointing behavior with children's utterance. The results show patterns of the pointing with utterance change corresponding to children's developmental stages. Also, one of the pointing patterns is found to have strong relationship with a certain type of picture books.
\end{abstract}

Keywords: Text Mining, Analyzing Children's Behavior, Knowledge Acquisition from Web.

\section{Introduction}

When children start to acquire language in their very initial stage, typical developmental sign called "labeling" tend to appear. Labeling is the sign that children recognize what the object of interest is, or how it appears to be. This sign starts to appear around 20 months after birth ${ }^{1,2}$ as the result of the complex cognitive development. For example, it is very difficult to identify apples coming into children's view in the different contexts, such as red apples, green apples and bearing apple trees in the different scenes in a picture book. 10 month old children cannot identify objects in the different context, ${ }^{3}$ they might recognize that red apples are completely different objects with the green ones. According to Ref. 3, 14 month old children show the developmental sign that they try to find out the common characteristics in the objects appearing in different contexts with the same verbal annotation from their mothers. Label- 
ing is said to be realized after those kinds of cognitive developments. ${ }^{4}$

Pointing behavior, the behavior pointing objects of interest with fingers, is found to be the typical behavior involved with developmental procedure to realization of labeling, and various research have been done to find out the relation between pointing behavior and language acquisition. ${ }^{5,6,7}$ In addition, pointing behavior is widely used as the diagnostic index of developmental disorder for 1.5 year old children. ${ }^{1}$

Meanwhile, picture books are admitted to assist developmental procedure for labeling, by means of their cognitive structure symbolizing the characters in the scenes, and verbal annotations to the characters during picture book reading by their mothers. ${ }^{8}$ Furthermore, pointing behavior during picture book reading accompanied by spontaneous vocalizations tends to be incrementally frequent with their developmental stages. ${ }^{7,9}$ These observations imply that picture books might stimulate cognitive development for labeling thereby have some effects on language acquisition. Several research have tried to analyze the effects by observing the characteristics of children's pointing behaviors with vocalizations during picture book reading. ${ }^{10,11}$ However, any of the research is not based on sufficient variations of data so that the analysis of observed characteristics of pointing behavior are not persuasive enough to explain how the observations are corresponding to the theory of labeling and language acquisition.

In this paper, we analyze pointing behaviors extracted from a large amount of picture books' reviews in which parents depict their children's reactive behaviors during picture book reading. We make use of reviews written on Ehon-navi ${ }^{*}$ the Web site specialized in picture books where approximately 330 thousand reviews are written. Firstly we compare the characteristics of pointing behavior in the reviews to those of the results of empirical research on picture book reading to evaluate the coincidence. Then, we try to analyze the relation between the characteristics of pointing behavior and the one of each of picture book, which is unique to our work because the related these empirical studies have not covered ample variations of picture books. Finally, we gain an insight into the results of the analysis, and try to explain language acquisition mechanism behind the pointing behaviors referring to previous studies on language acquisition.

\section{Empirical Studies on Pointing Behavior with Vocalization during Picture Book Reading}

The results of empirical research on the developmental effects of picture book reading often differ with each other despite of the same hypothesis. Those difference might be caused due to the experimental environment, having mothers read unfamiliar picture books or making them unfamiliar style of picture book reading. ${ }^{8}$ Moreover experimental picture book reading imposes burden on both of the subjects and the conductor, resulting in insufficient volume of samples. Table 1 shows examples of the research samples.

In this research, we analyze large amount of text reflecting pointing behavior with vocalization written in reviews on picture books. Those of the text data differ from the empirical data above in that they reflect children's pointing behaviors which occur in ordinary scene of day to day life, and also reflect children's responses to large varieties of picture books.

Table 1. Examples of Empirical Research Samples

\begin{tabular}{|c|c|c|c|}
\hline $\begin{array}{l}\text { Research } \\
\text { Work }\end{array}$ & $\begin{array}{l}\text { Number of } \\
\text { children }\end{array}$ & $\begin{array}{lr}\begin{array}{l}\text { Number } \\
\text { Picture }\end{array} & \text { of } \\
\text { Beading } & \\
\end{array}$ & $\begin{array}{l}\text { Number } \\
\text { of Picture } \\
\text { Books }\end{array}$ \\
\hline Sugai 11 & 9 & 20 & 3 \\
\hline Tatsuno $^{10}$ & 20 & 3 & 6 \\
\hline
\end{tabular}

\section{Extracting Pointing Behaviors Accompanied by Vocalizations from Reviews on Picture Books}

Based on the reviews written on Ehon-navi, we extracted those that include the word "pointing".. Further extraction is done based on the condition that Japanese vocalizing symbols " $\Gamma$ " and “」” cooccurring with "pointing" in a review.

*http://www.ehonnavi 
After the extractions, we manually classify the reviews into types of each categories above. Simultaneously we exclude the reviews depicting mothers' pointing behaviors but not the children's ones. The result of the extractions is as follows. Total number of reviews including "pointing" amounts to 1,071. Reviews in which the symbols " $\Gamma$ " and "」 " co-occurring with "pointing" amounts to 691. Out of them 405 reviews are the ones of children's responses and the rest are not. So the ratio of children's response to the total number of reviews including "pointing" is $37.8 \%$. Fig. 2 shows the frequency of the extraction by each age of children. Both of the number of reviews including "pointing" and reviews including "pointing" co-occurring with " $\Gamma$ " and "」" has the same peak at age 1. Meanwhile, the ratio of the reviews of co-occurrence to the ones including "pointing" increases in proportion to children's age. Fig. 1 and Fig. 2 show similar frequency resulting from the empirical research of pointing behavior during picture book reading by Ref. 10. Although the number of the samples and the range of children's age are restrictive, pointing behavior shows its peak at the age of 18 months, and the accompanying ratio of vocalization increases in proportion to the age. The other empirical research has demonstrated that frequency of the pointing behavior tends to decrease from 1.5 year of age to 3 year of age. Our analysis above are coincident with these findings.

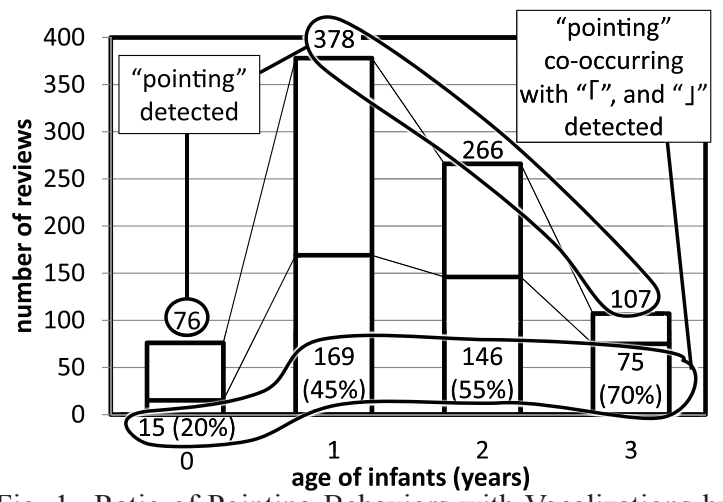

Fig. 1. Ratio of Pointing Behaviors with Vocalizations by Each Age (a): Picture Book Reviews (studied in this paper)

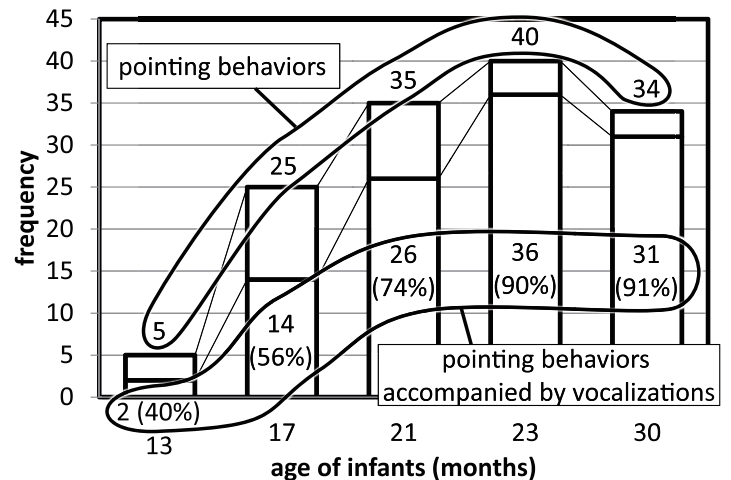

Fig. 2. Ratio of Pointing Behaviors with Vocalizations by Each Age (b): Empirical Research on Pointing Behaviors during Picture Book Reading (studied in Ref. 10)

\section{Categorizing Pointing Behaviors Accompanied by Vocalizations}

Given the data extracted from the picture book reviews as above, we analyze the characteristics of pointing behavior in terms of how they comply with the findings of the empirical studies on picture book reading. In general, the approach of those studies is to classify the characteristics of pointing behaviors, and analyze how they change in accordance with children's age. We classify pointing behaviors in the same manner as those empirical studies did in order to consider their coincidence.

Although varieties of categories have been proposed previously, we define 3 categories each of which comprises of several types of pointing behaviors. Those categories used in this paper are based on those proposed in a recent study. ${ }^{11}$ which take the categories proposed in the preceding studies into consideration. Adopted categories and their types are as follows.

\section{Category 1: The intention of pointing behavior}

\section{Explanation ;}

The pointing behavior for explaining the pointing object

\section{Question ;}

The pointing behavior for asking someone of the pointing object 


\section{Response ;}

The pointing behavior for responding to someone's question

\section{Request ;}

The pointing behavior for asking someone for something he or she wants

\section{Labeling ;}

The pointing behavior with speech production to annotate the object by its name or the characteristics

\section{Exploration ;}

The pointing behavior for exploring something

\section{Analogy ;}

The pointing behavior for recognizing analogous objects

\section{Interests ;}

The pointing behavior for expressing his or her curiosity

Additionally, we define sub-types for labeling because the objects of labeling alter in accordance with the developmental stages. ${ }^{12}$ Based on Ref. 12, we define the types of the sub-categories as follows.

- names

- colors

- tastes

- emotion

- size

- number

- sentence

\section{Category 2 : Pointing objects}

\section{Letters ;}

Pointing to letters printed on picture books

\section{Physical Objects ;}

Pointing to objects existing in his or her surroundings

\section{Illustrations ;}

Pointing to picture books' illustrations

\section{Category 3 ; Types of vocalizations}

- bubbling

- onomatopoeia

- words

- sentences

Table 2 lists some of examples of reviews of categories $1 \sim 3$ above.

\section{Analyzing Frequencies of the Classified Types of Pointing Behavior Accompanied by Vocalizations for Each Age}

Based on the categories and the types introduced in Section 4 above, we manually classified the reviews including pointing behaviors with vocalizations extracted in Section 3, and analyze the frequency by each age of children. Fig. 3, Fig. 4, and Fig. 5 show the results corresponding to the categories 1,2 , and 3 , respectively. The graph of each age represents the component ratio of each type setting each frequency to 100 .

The analysis of the frequency are described below with comparison to empirical research of pointing behaviors with vocalizations during picture book reading. As described in Section 4, general approach of empirical studies on pointing behaviors with vocalizations during picture book reading is to analyze how characteristics of pointing behaviors during picture book reading change in accordance with children's age, thereby to clarify the effects of picture book reading on language development. As described above, experiments of those previous studies are restricted in terms of the volume of samples and the range of children's ages. Thus, their findings are not reliable enough and it is worthwhile to ensure overall coincidence between the findings of those previous studies on language acquisition and the ones we examine in this paper that are based on picture book reviews. Comparisons below are executed by aggregating the fragmentary results of each of the research. 
Table 2. Examples of Reviews of Categories 1 3

\begin{tabular}{|c|c|c|c|c|}
\hline \multirow[b]{2}{*}{ ID } & \multirow[b]{2}{*}{ Excerpts from a Review } & \multicolumn{3}{|c|}{ Categories $1 \sim 3$} \\
\hline & & $\begin{array}{l}\text { category } 1 \\
\text { (intention) }\end{array}$ & $\begin{array}{l}\text { category } 2 \\
\text { (pointing } \\
\text { objects) }\end{array}$ & $\begin{array}{c}\text { category } 3 \\
\text { (types of } \\
\text { vocalizations) } \\
\end{array}$ \\
\hline 1 & $\begin{array}{l}\text { 赤いいちごだけでなく緑のもみつけて教えてくれたりい緒に楽しめる絵本です。 } \\
\text { て教えまだ食べれんね」つて指さし } \\
\text { ( She points not only to red strawberries but also to green ones, and } \\
\text { says “I cannot eat this yet”. Parents together with children can enjoy } \\
\text { this picture book.) }\end{array}$ & explanation & illustrations & sentences \\
\hline 2 & $\begin{array}{l}\text { 最近の娘は、字にも興味が出てきたのか、絵本の字の部分を指さして } \\
\text { 「なんて書いてあるの?」という回数が増えてきています。 } \\
\text { ( Recently, my daughter likely becomes interested in letters, and more } \\
\text { and more frequently asking “What does this letter mean?”. ) }\end{array}$ & question & letters & sentences \\
\hline 3 & 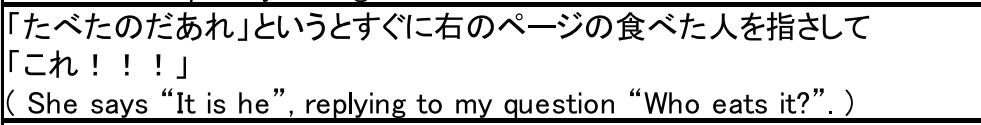 & response & illustrations & words \\
\hline 4 & $\begin{array}{l}\text { 子どもも「あ、この本知ってる!」指さしてうれしそうでした。思わずプッと } \\
\text { 笑ってしまうュ一モア溢れる箇所もあり、3歳児にはは面白い絵本だったよう } \\
\text { です。今はまだ「読んで。読んで」とせがむばかりです。 } \\
\text { ( He enjoys it, saying “I know this book” and pointing to it. The book is } \\
\text { full of humorous scenes, and make three year old boy happy. He is now } \\
\text { just asking “Read it for me”.) }\end{array}$ & request & illustrations & words \\
\hline 5 & $\begin{array}{l}\text { この絵本と本物の月を交互に指さしながら、「まんまるおつきさま」、 } \\
\text { 「おつきさま、わらつた」と毎晚のように言っています。 } \\
\text { ( He points to the moon on the picture book and the real one } \\
\text { alternatively, and saying every evening “The round moon is laughing”. ) }\end{array}$ & $\begin{array}{l}\text { labeling } \\
\text { (name) }\end{array}$ & $\begin{array}{c}\text { physical } \\
\text { objects }\end{array}$ & sentences \\
\hline 6 & $\begin{array}{l}\text { 最近、色を覚えて興味があるのか子供がしろぶたくんの体を指さして } \\
\text { いっしょうけんめい「あか」とか言っていました。 } \\
\text { ( Recently, my son looks interested in colors, and says “This is red”, } \\
\text { pointing to the pig's body.) }\end{array}$ & $\begin{array}{l}\text { labeling } \\
\text { (color) }\end{array}$ & illustrations & words \\
\hline 7 & $\begin{array}{l}\text { Гこわい」と言うので、何が怖いの? ?聞くと、ハンターを指さして「これ } \\
\text { こわい、あっちやっとくか」と言いながら、本を片づけてしまいました。 } \\
\text { ( He said “It is scary”. I asked him why. Then, he pointed to the hunter } \\
\text { on the picture book and said “It is scary. I'm going to take away.” and } \\
\text { put away by himself. ) }\end{array}$ & $\begin{array}{l}\text { labelling } \\
\text { (emotion) }\end{array}$ & illustrations & sentences \\
\hline 8 & 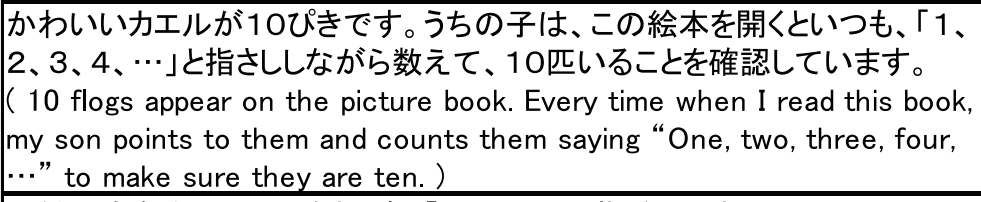 & $\begin{array}{l}\text { labeling } \\
\text { (number) }\end{array}$ & illustrations & sentences \\
\hline 9 & $\begin{array}{l}\text { 子供は金魚を見つけ、自慢げに「ここ！」つて指差します。 } \\
\text { ( She looks for a goldfish and finds one, then proudly points to it saying } \\
\text { “Here!”.) }\end{array}$ & exploration & illustrations & words \\
\hline 10 & $\begin{array}{l}\text { うちのお風呂にあひるさんのおもちやがあるのですが、この本にもそれが } \\
\text { 描かれていて娘は「あ! ガーガー! (あひる)」と指差して喜んでいます。 } \\
\text { ( We ourself bought a toy duck and have it in our bathroom. A toy duck } \\
\text { is illustrated also in the picture book, where she enjoys it and she } \\
\text { points to it saying that “Oh! Quack-quack! (a duck)” ) }\end{array}$ & analogy & illustrations & onomatopoeia \\
\hline 11 & $\begin{array}{l}1 \text { 歳半の下の子も、パンダを指さして、「あ! あ! ! ! 」と大喜びでした。 } \\
\text { ( One and a half year old boy points to the panda, and expresses his joy } \\
\text { saying “Ah! Ah!”) }\end{array}$ & interests & illustrations & bubbling \\
\hline
\end{tabular}




\subsection{Analyzing Frequencies of the Intentions of Pointing Behaviors Accompanied by Vocalizations}

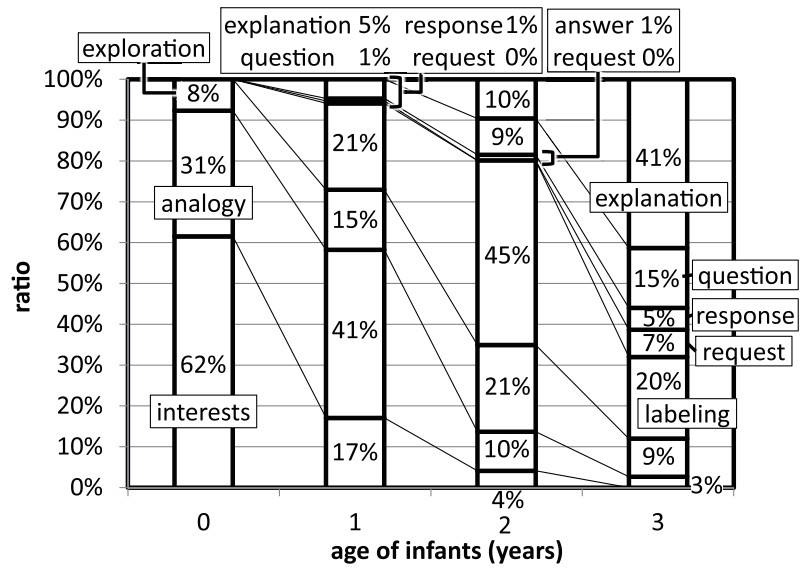

Fig. 3. Frequencies of the Intentions of Pointing Behaviors Accompanied by Vocalizations

\subsubsection{The Intention of Interests}

Vocalizations along with pointing behaviors start from $11^{13}$ month or 12 month $^{14}$ after birth, and the vocalizations tend to be expression of interests. The graphs of 0 and 1 year old children in Fig. 3 show the coincidence with the empirical results of Ref. 13,14.

\subsubsection{The Intention of Analogy}

The pointing behavior intending analogical comparison starts from 11 month after birth and it lasts until 15 month. ${ }^{1}$ Its emergence at the age of 0 and the peak at the age of 1 in Fig. 3 show the coincidence with the empirical results of Ref. 1.

\subsubsection{The Intention of Labeling}

Labeling behaviors show their peaks around 18 month ${ }^{11}$ to 21 month $^{10}$ followed by decreasing frequency. The graph in Fig. 3 shows its peak at the age of 2 year, which is slightly different from the empirical results of Ref. 10,11.

\subsubsection{The Intention of Question and Explanation}

The pointing behaviors intending question and explanation show their peaks around 30 month. ${ }^{11}$ Corresponding graphs in Fig. 3 show their peaks at the age of 3 , which is slightly different from the empirical results of Ref. 11.

\subsection{Analyzing Frequencies of the Pointing Objects}

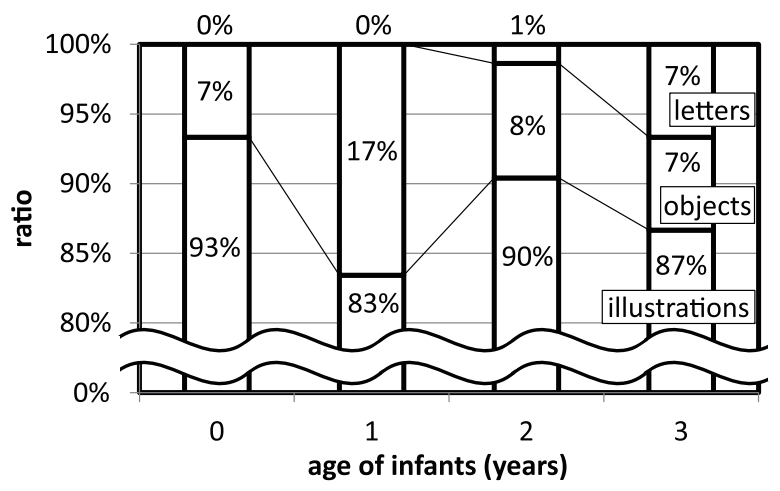

Fig. 4. Frequencies of Pointing Objects

According to the research, ${ }^{11}$ frequencies of pointing to illustrations of picture books are constant regardless of children's age. Pointing to real objects are observed $15 \%$ of pointing behaviors around 1.5 to 2.5 year of age, and are not observed at 3 year of age. Pointing to printed letters are observed $5 \%$ of pointing behaviors around 2.5 to 3 year of age.

In comparison with the empirical research above, Fig. 4 shows the frequencies of the pointing objects. Pointing to illustrations appear to be constant in the graphs, coincident with the findings of the research above. Meanwhile, pointing to real objects and to printed letters show their peaks at 1 and 3 year of age, respectively, which is slightly different from the research findings of Ref. 11. Because the number of empirical data are 18, 23 and 18 at 1.5, 2.5 and 3 year of age, respectively, any of which is insufficient, the difference should be considered as the suggestion. 


\subsection{Analyzing Frequencies of the Types of Vocalizations}

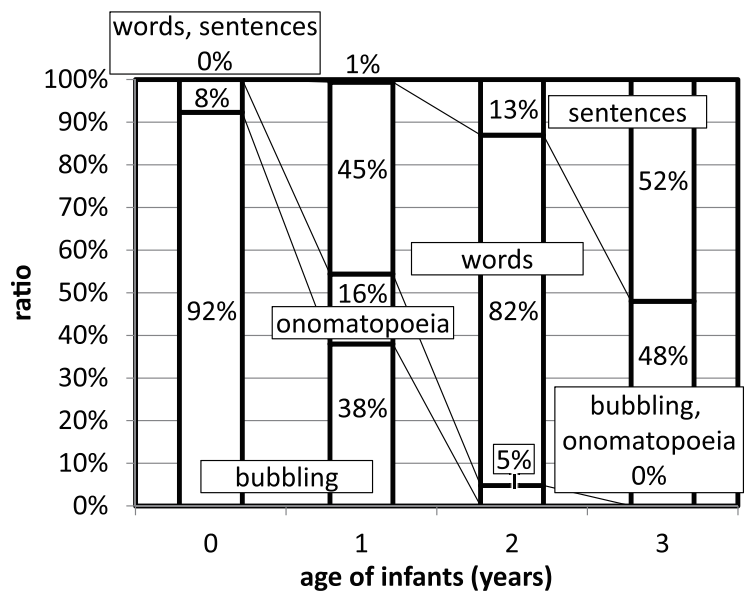

Fig. 5. Frequencies of the Types of Vocalizations

According to Ref. 10, bubbling, one word utterance and speaking sentences show their peaks at 13, 21 and 30 month of ages, respectively, though the range of children's age is limited from 13 month to 30 month of age. Meanwhile frequencies of vocalization types are on Fig. 5. The peak of bubbling appears at 0 year of age, and also occupies large portion at 1 year of age. One word utterance, and speaking sentences show their peaks at 2 and 3 year of age, respectively.

\section{The Relation between Types of Pointing Behaviors and the Characteristics of Picture Books}

As described before, any of the empirical research concerning the picture book reading have not dealt with sufficient data, so that the variations of the picture books have been very limited. Therefore, the research concerning the relation between the types of pointing behaviors and the characteristics of picture books have not been found at all.

We try the qualitative analysis, taking "exploration" in the intentions of pointing behaviors as an example. Table 3 shows the titles of picture books having more than 2 reviews meaning exploration. Characters appearing in any of these titles behave so as to emphasize their existence, by the repetition of hiding and reappearing or by the repetition of running away and going back etc.

If mothers point to a scene illustrating a chick in a pond saying "This is a chick", children in their very early stage might recognize depicted chick together with a pond as a chick. As mothers point to a chick in the different contexts such as a chick in the different scene of the picture book or a toy of a chick, they gradually become aware of common characteristics of a chick leading to precise recognition for a chick. ${ }^{15}$ Picture books above might assist such cognitive development, because the repetition of scenes illustrating a character and the scenes not illustrating it makes clear for children to be aware of the character independent of different contexts.

Table 3. The Picture Books Stimulating Pointing Behavior Intending "Exploration"

\begin{tabular}{|c||c|}
\hline \multicolumn{1}{|c||}{ Title of Picture Books } & $\begin{array}{l}\text { Frequencies of } \\
\text { Pointing Behav- } \\
\text { ior Intending } \\
\text { "Exploration" }\end{array}$ \\
\hline \hline Hide and Seek of a Quail & 5 \\
\hline Gold Fish Is Running Away & 24 \\
\hline Someone is There & 2 \\
\hline I Found It ! & 2 \\
\hline A Balloon Hide Non-tan Away & 2 \\
\hline
\end{tabular}

\section{The Relation between Pointing Behaviors in the Reviews and Development for Language Acquisition}

Typical preceding behaviors to initial language establishment are that children try to find out the common characteristics in the objects appearing in different contexts with the same verbal annotation from their mothers. ${ }^{3}$ Pointing gestures at this stage represent children gradually become aware that objects with common characteristics have their own name. Exploratory behaviors in the previous section are considered to be expression of the awareness.

These kinds of pre-language behaviors can be observed from combinational analysis of "Analogy" in Fig. 3 and "pointing real objects" in Fig. 4. "Analogy" in Fig. 3 occupies the largest portion at the age of 1 . Also, behavior of pointing real objects indicates its peak equivalent to 28 reviews at the age of 
1 in Fig. 4, and 20 out of the 28 reviews are the ones classified as "Analogy". As such,"Analogy" occupies the largest portion also in the behavior of pointing real objects at age 1 . These behavioral characteristics represent the children's efforts to find out common characteristics between the depicted object on the picture book and real ones, implying the same behavior as pointed out in the previous study.

As described above, labeling is a typical behavior appearing at very initial stage of language acquisition. In addition, labeling itself can be classified into several stages of developments. ${ }^{15,12}$ At the initial stage around the age of 2 and 2.5, labeling to the name of objects are overwhelming. After that, labeling evolves into adjectives or verbs to express the feature of objects. In general, labeling of names consists of one or two words, meanwhile labeling by verbs tends to be sentences. In addition, labeling to the number of objects starts after the age of $3 .{ }^{15}$

In order to elaborate the features of labeling behavior in the reviews, we further classified the reviews into sub-types of labeling as follows.

names, colors, tastes, emotion, size, number, sentence

Fig. 6 shows the frequencies of the sub-types by age. The portion of labeling to names is overwhelming at the age of 1 and 2. At the age of 3, the portion decreases, and labeling to number increases. Again these results are coincident with labeling behavior asserted by the research of language acquisition. Meanwhile, labeling by sentences does not show expected change. Further research is necessary in this respect.

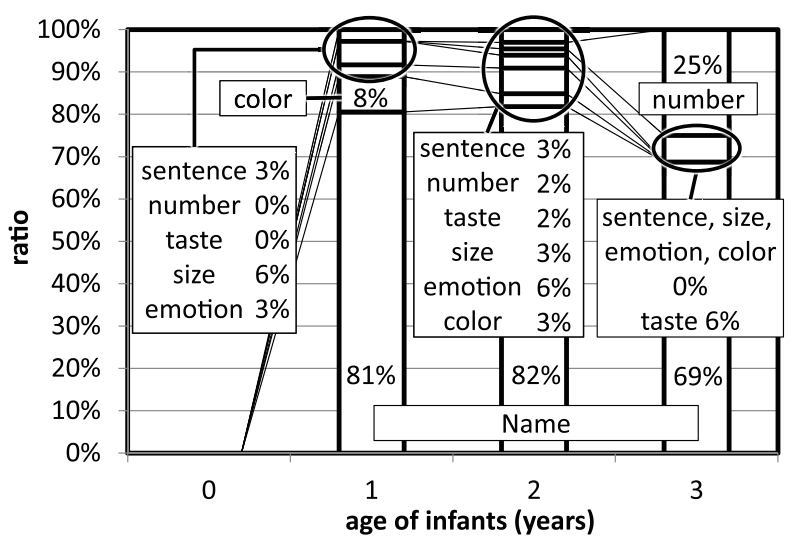

Fig. 6. Frequencies of sub-types of labeling

\section{Conclusion}

Previous work on pointing behaviors during picture book reading have adopted various categories to study developmental patterns of pointing behaviors. Although the research findings suggest that patterns of classified pointing behaviors change in accordance with children's age represent the characteristics of the development in language acquisition, the findings are not reliable enough because they have been based on limited empirical data in terms of the range of ages, the variations of picture books, etc. Additionally due to this scarcity of sample data, those previous studies have not analyzed the stimulus for pointing behaviors contained in picture book reading. In this paper, we aim to overcome this limitations by making use of a large amount of reviews, and to try to verify whether the way patterns of pointing behaviors change in accordance with children's age comply with the previous research findings. A large amount of data also enables a further analysis that are quite original in this paper, where we concern how the variety of picture books' styles work as the stimulus for pointing behaviors. We analyze the relation between exploratory pointing behaviors and patterns of picture books, thereby try to find out one of the stimulus.

The results show that the way patterns of categorized pointing behaviors change in accordance with children's age are consistent with the previous work's findings though the coincidence are limited to the range of data used in those previous work. Also, the picture books emphasizing the contrast between appearing characters and disappearing characters are found to stimulate the pointing behaviors of exploration.

Furthermore, our additional analysis of the reviews bring about some insight into the mechanism of language acquisition. According to those studies on language acquisition, pointing behavior is an indispensable cognitive process for language acquisition. Those findings of our analysis support the assertions. Children in their pre-language 
stage are found to express their awareness of analogy by pointing, comparing objects depicted on picture books with the real ones.

\section{References}

1. E. Hatano, "The developmental significance of pointing behavior," Japanese Journal of Educational Psychology, vol. 31, no. 3, pp. 255-264, 1983.

2. K. Ohama, T. Tatsuno, K. Saito, S. Takei, and M. Ogino, "Development of pointing in mother-infant interaction : Analysis of time series data," Japanese Journal of Educational Psychology, vol. 29, no. 3, pp. 272-278, 1981, (in Japanese).

3. C. L. Stager and J. F. Werker, "Infants listen for more phonetic detail in speech perception than in wordlearning tasks," Nature, vol. 88, pp. 381-382, 1997.

4. M. Imai and E. Hanyu, Constructing Lexicon. Iwanami Shoten Publishers, 2007, (in Japanese).

5. J. D. Bremner and A. Slater, Theories of Infant Development. Wiley-Blackwell, 2004.

6. M. Tomasello, M. Carpenter, and U. Liszkowski, "A new look at infant pointing," Child Development, vol. 78, no. 3, pp. 705-722, 2007.

7. C. M. Murphy, "Pointing in the context of a shared activity," Child Development, vol. 49, no. 2, pp. 371380, 1978.

8. Y. Ishikawa and H. Maekawa, "A tendency of shared picture-book reading," Bulletin of Disability Sciences, vol. 24, pp. 227-240, 2000, (in Japanese).
9. M. Senechal, E. H. Cornell, and L. S. Bronda, "Agerelated differences in the organization of parentinfant interactions during picture-book reading," Early Childhood Research Quarterly, vol. 10, no. 3, pp. 317-337, 1995.

10. T. Tatsuno, K. Saito, S. Takei, M. Ogino, and K. Ohama, "The development of verbal behavior (IV) : Pointing in mother-infant interaction : Longitudinal study of infants from 13 to 30 months old," Bulletin of the School of Education, the University of Tokyo, vol. 21, pp. 77-78, 1981, (in Japanese).

11. Y. Sugai, "Developmental research in mother-child interaction during picture-book reading," The Annual Report of Educational Psychology in Japan, vol. 21, no. 1, pp. 46-57, 2010, (in Japanese).

12. T. Ogura, "Initial language development of Japanese children," Language Research, vol. 132, pp. 29-53, 2007, (in Japanese).

13. T. Koyama and S. Mishima, "Development of joint attention related behaviors of infants: Transitional process from dyadic to triadic interactions," Psychology Research of Kyusyu University, vol. 14, pp. 99-109, 2015, (in Japanese).

14. H. Ohgami, "The developmental origins of early joint attention behaviors," Kyushu University Psychological Research, vol. 3, pp. 29-39, 2002, (in Japanese).

15. M. Imai, Challenging the Mystery of Children's Language Development. Chikuma Shobo, 2010, (in Japanese). 